\title{
Gene Therapy For Ischemic Heart Disease
}

\author{
Madhav Lavu, M.D' ${ }^{1}$, Susheel Gundewar, M.D², and David J. Lefer, Ph.D1 \\ ${ }^{1}$ Department of Surgery, Division of Cardiothoracic Surgery and the Carlyle Fraser Heart Center, \\ Emory University School of Medicine, Atlanta, GA 30308 \\ 2 Department of Medicine, Division of Cardiology, Albert Einstein College of Medicine, Bronx, NY \\ 10461
}

\section{Abstract}

Current pharmacologic therapy for ischemic heart disease suffers multiple limitations such as compliance issues and side effects of medications. Revascularization procedures often end with need for repeat procedures. Patients remain symptomatic despite maximal medical therapy. Gene therapy offers an attractive alternative to current pharmacologic therapies and may be beneficial in refractory disease. Gene therapy with isoforms of growth factors such as VEGF, FGF and HGF induces angiogenesis, decreases apoptosis and leads to protection in the ischemic heart. Stem cell therapy augmented with gene therapy used for myogenesis has proven to be beneficial in numerous animal models of myocardial ischemia. Gene therapy coding for antioxidants, eNOS, HSP, mitogen-activated protein kinase and numerous other anti apoptotic proteins have demonstrated significant cardioprotection in animal models. Clinical trials have demonstrated safety in humans apart from symptomatic and objective improvements in cardiac function. Current research efforts are aimed at refining various gene transfection techniques and regulation of gene expression in vivo in the heart and circulation to improve clinical outcomes in patients that suffer from ischemic heart disease. In this review article we will attempt to summarize the current state of both preclinical and clinical studies of gene therapy to combat myocardial ischemic disease.

\section{Keywords}

gene transfer; cardiovascular therapy; ischemic heart disease

\section{Introduction}

Coronary heart disease (CHD) is the single leading cause of death in adults in the US, accounting for 1 in 5 deaths. According to the American Heart Association (AHA), prevalence of total cardiovascular disease in the US in 2006 was 81.1 million people, out of which 17.6 million people had coronary heart disease (myocardial infarction and angina pectoris). Among the people with CHD, the prevalence of heart failure (HF) was 5.8 million [1]. According to the AHA, estimated direct and indirect costs of coronary heart disease for the year 2010 is 177.1 billion dollars. Pharmacologic therapies for CHD and HF have multiple systemic side effects and are pre-disposed to several adverse drug interactions since

Address for Correspondence: David J. Lefer, Ph.D, Department of Surgery, Division of Cardiothoracic Surgery, Emory University School of Medicine, Carlyle Fraser Heart Center, 550 Peachtree St NE Atlanta, GA 30308, Phone (404) 686-1820, Fax (404) 686-4888,dlefer@emory.edu.

Publisher's Disclaimer: This is a PDF file of an unedited manuscript that has been accepted for publication. As a service to our customers we are providing this early version of the manuscript. The manuscript will undergo copyediting, typesetting, and review of the resulting proof before it is published in its final citable form. Please note that during the production process errors may be discovered which could affect the content, and all legal disclaimers that apply to the journal pertain. 
polypharmacy is frequently involved in the treatment of such patients. In addition, compliance is a major issue in these patients. Importantly, pharmacologic therapies aim to reduce symptoms and halt progression of disease but do not necessarily reverse the pathophysiology associated with CHD and HF. Additionally, interventional or surgical coronary revascularization procedures in patients with multiple stenotic lesions or disease in multiple vessels do not provide long term relief and frequently patients remain symptomatic despite maximal anti-anginal therapies and may require repeat revascularization procedures. The treatment of end stage HF is orthotopic heart transplantation and patients have to wait for a year or more due to unavailability of donor hearts.

Gene therapy offers an attractive solution due to the aforementioned limitations of current therapies. It provides continuous delivery of therapeutic proteins locally at the site of disease after a single application, and can potentially lead to reversal of pathophysiology associated with acute myocardial infarction. Gene modification using novel gene constructs can allow genes to be switched on and off depending on the intracellular milieu and minimize unwanted side effects from unrestricted protein synthesis or inhibition. Stem cell-based therapies promote cardiac regeneration and have a higher rate of success when combined with gene therapy [2] [3,4]. Gene therapy can therefore potentially delay the need for heart transplantation or may even obviate the need for one by reversing the pathology, improving cardiac function and alleviating symptoms.

Gene therapy results in synthesis or inhibition of specific proteins leading to alterations in structure or function of the cells in the target tissues. The first step in gene therapy is to design the gene construct with the promoter/enhancer and other stabilizing sequences targeting the gene of interest. The construct is then integrated into the viral genome or a plasmid producing a vector or a delivery vehicle for the gene. The next step is delivering the transgene into the target cells to promote gene expression. Naked plasmid DNA by itself has low transfection efficiency and hence, delivery vectors in the form of adenoviruses, adenoassociated viruses, retroviruses and non-viral vector systems are needed to transfect target cells significantly. Specialized catheters deliver the vectors carrying transgenes into either coronary vessels or into the myocardium. In addition, pericardial administration and invasive surgical intra myocardial approaches have been employed.

In this review we discuss the current preclinical gene therapy studies in in vivo models of myocardial ischemia. We describe various gene therapy modalities that in animal models have shown to be of benefit while targeting different dysfunctional aspects of ischemic heart disease. These models are critical in determining which therapies are suitable for clinical investigation.

\section{Gene Therapy for Angiogenesis to Combat Ischemia VEGF Gene Therapy}

VEGF is perhaps the most highly investigated growth factor that has been studied to induce angiogenesis in the ischemic heart. Isoforms of VEGF bind to specific receptors on endothelial cells and play an essential role in angiogenesis [5]. The mammalian genome encodes five isoforms of the VEGF family, which are VEGF-A, VEGF-B, VEGF-C, VEGF$\mathrm{D}$ and placental growth factor [6]. VEGF-A and VEGF-B signal via VEFG receptor-1 and VEGF receptor-2 and regulate blood vessel physiology [7-10].

VEGF-A plays a key role in angiogenesis in the heart [6], especially during hypoxia and nutrient deprivation [11,12]. Transcripts encoding its isoforms VEGF-121 and VEGF-165 are detected in the majority of cells and tissues expressing the VEGF gene. VEGF-121 lacks the amino acids encoded by exon 7 of the VEGF gene, which is present in VEGF-165 and 
enables VEGF-165 to bind to heparin and heparin sulfate. Gene therapy of VEGF-165 has been found to be highly potent for promoting angiogenesis [13]. VEGF-165 gene therapy mediated through plasmids in rats $[14,15]$ or through non-viral delivery systems in rabbits [16] induces significant neovascularization and improves fractional shortening after myocardial infarction (MI). In porcine models of MI, VEGF-165 has been shown to increase myocardial blood flow, increase vasodilation with adenosine [17], improve wall thickening and strain [18], improve wall motion[19], increase ejection fraction [20] and increase myocardial viability [21] thereby leading to significant overall improvement in cardiac function. Additionally, VEGF-121 gene therapy augments collateral circulation following $\mathrm{MI}$ in rats [22], and in a porcine model of chronic myocardial ischemia [23]. Efficacy of VEGF-121 and of VEGF-165 gene therapy is accentuated with the use of transmyocardial laser, which results in increased capillary formation [24], and improved wall motion [25] in pig models of cardiac ischemia.

VEGF-B is highly expressed in tissues rich in mitochondria, such as the heart, skeletal muscle and brown adipose tissue [26] and plays an important role in revascularization of the ischemic myocardium [27]. Overexpression of VEGF- B186 after cardiac ischemia in pigs and rabbits leads to improved myocardial perfusion and ejection fraction [28]. Similarly VEGF-C gene therapy demonstrates increased collateral formation and reduced wall thickening after myocardial ischemia in piglets. [29] VEGF-D in normal porcine heart has also proven to improve perfusion when administered through the catheter mediated intramyocardial gene transfer [30]. Taken together these studies show that expression VEGF via gene therapy in animal models significantly promotes angiogenesis and improvements in cardiac function following myocardial injury. Angiogenic therapies are not without drawbacks however and unregulated expression limits the efficacy and safety of VEGF gene therapy [31-33]. To circumvent this hurdle, novel gene constructs have been developed whose expression can be switched on or off depending on cellular environments. These constructs have shown to achieve increased VEGF levels during cardiac ischemia [34,35], lead to improved infarct size [36] and induce angiogenesis [37].

\section{Hepatocyte Growth Factor Gene Therapy}

Hepatocyte growth factor (HGF) is secreted by mesenchymal cells and acts as a multifunctional cytokine targeting cells of epithelial origin. HGF binds to a tyrosine kinase receptor on vascular endothelial cells thus affecting their migration, proliferation, protease production, invasion and neovascularization [38]. Human HGF (hHGF) gene therapy has been shown to induce angiogenesis in rats and dogs after MI [39-41]. Additionally, it has been shown to improve remodeling [42,43], decrease apoptosis [44,45], improve mobilization of stem cells for cardiac repair [46], decrease fibrotic scar formation [47,48], and improve contractility of the heart [49,50]. HGF gene therapy has proven effective when combined with ultrasound mediated microbubble destruction in an effort to improve gene transfection in a rat model of MI [51] and is currently being evaluated in clinical trials.

\section{Fibroblast Growth Factor Gene Therapy}

Fibroblast growth factors (FGFs) bind to tyrosine kinase receptors and mediate mitogenic and cell survival activities. FGFs promote tissue growth and affect cellular proliferation and migration [52,53]. FGF family members differ from one another in their ligand affinities and tissue distribution. FGF-1 and FGF-2 promote endothelial cell proliferation and the physical organization of endothelial cells into tube-like structures. FGF-2 gene therapy has been shown to consistently improve arteriogenesis and echocardiographic parameters of left ventricular (LV) function in chronic ischemia in pigs [54,55]. FGF-2 dependent pathway is activated following the delivery of a "master switch" gene called PR39, which when overexpressed also activates VEGF dependent pathways and leads to improved myocardial 
perfusion in a porcine model of chronic ischemia [56]. FGF-4 and FGF-5 are secretory FGFs that have further advantages and may cause paracrine and endocrine effects when compared to FGF-1 and FGF-2, which are primarily intracellular. FGF-4 gene therapy results in increased perfusion and decreased dysfunction in stress induced MI in pigs [57] while FGF-5 gene therapy not only improves blood flow [58] but also reduces pacing induced regional myocardial dysfunction by stimulating the mitotic replication of myocytes, leading to an increase in LV mass [59].

\section{Angiogenesis through Gene Modified Cells}

Gene modified cells act as transgene carriers when they have been transfected with the gene of interest. These cells have the ability to overexpress the transgene and lead to increased levels of therapeutic proteins in target tissues. The potential benefit of cell-based therapy lies in the ability of the myogenic cells to differentiate into a cardiac phenotype, become a part of the myocardium and prevent adverse LV remodeling [60]. The transfected cells also express the transgene to produce sustained growth factor release, which then promotes angiogenesis and improves cell implantation and survival. Cells derived from a variety of sources have been employed. Vascular smooth muscle (VSMC) cells modified to overexpress VEGF, when administered via intra coronary route in an intermittent repetitive LAD occlusion model increase collateral circulation in the ischemic heart [61]. Fibroblasts, gene modified to overexpress bFGF gene, when administered by coronary injections in a swine model of chronic ischemia lead to improved collateral formation and myocardial contraction as measured by coronary angiography and electromechanical mapping [62].

Skeletal myoblasts (SkMs) modified to overexpress VEGF, when transplanted in MI models, not only increase angiogenesis and improve cardiac contractile function $[2,63,64]$ but also decrease the amount of apoptosis in the ischemic heart [3]. In a rat model of MIinduced by cryogenic injury, delivering SkMs overexpressing the growth factor VEGF leads to an improvement in the survival of these transplanted SkMs making them available in the ischemic tissue for extended periods [65]. In addition, transplantation of SkMs transfected to overexpress angiopoietin [4] and SDF-1alpha [66] also enhanced angiogenesis and improved LV function in the ischemic heart. Furthermore, SkMs transfected with adenovirus to overexpress HIF-1alpha improved transplanted cell survival, cell engraftment and angiogenesis after rat MI [67]. Thus, SkMs have been used to produce both angiogenic and pro-survival factors in the ischemic heart.

Some advantages of MSCs are their ability to be transduced by vectors easily, ability to be delivered systemically and their capacity to home in to damaged tissues. MSCs also possess low immunogenicity and hence can be used allogenically [68]. As transgene carriers, MSCs have been used to overexpress angiogenic growth factors such as VEGF-165 [69], FGF-1 [70], HGF [71] leading to increased vessel density and improved perfusion of the ischemic heart. Transplanted MSCs modified to express Akt were resistant to apoptosis [72], attenuated remodeling [73] and were found to have anti-apoptotic actions on distant ischemic myocardial cells away from their sites of injection[74]. Other single genes used in transfection of MSCs for treating the ischemic heart were angiogenin [75], HSP20 [76], BCL-2 [77], HO-1 [78], Shh [79] which showed neovascularization, decreased fibrosis, improved contractile function, improved remodeling and improved graft cell survival of the ischemic heart respectively. All the therapies mentioned so far have utilized the overexpression of a single gene. Multiple gene expression by transplanted cells has also been achieved. MSCs have been modified to express a combination of angiopoietin- 1 and Akt [80], which led to improved survival of transplanted cells, increased blood vessel density and improved fractional shortening and ejection fraction in the ischemic heart. Other combinations achieved through cell based gene delivery were VEGF with IGF-1 [81] and VEGF with bFGF [82], resulting in improvement in EF and decreased scar formation after 
MI. Apart from the above-mentioned cells, cord blood stem cells after gene modification to overexpress VEGF with PDGF [83] and angiopoietin-1 [84] have also been used leading to angiogenesis after rat MI. Thus we see cell based gene delivery improves angiogenesis in the ischemic heart through expression of angiogenic factors while the transplanted cells perform myogenic and regenerative functions in the ischemic heart.

\section{Gene Therapy for Myocardial Reperfusion Injury}

\section{Gene Therapy and Oxidative Stress}

Oxidative injury plays a critical role in several cardiovascular diseases including myocardial infarction, myocardial ischemia/reperfusion (MI/R) injury, atherosclerosis, endothelial dysfunction, restenosis, hypertension and cardiomyopathies and heart failure [85-89]. Reactive oxygen species (ROS) formed during I/R injury not only cause lipid peroxidation and protein oxidation but also affect several calcium handling proteins such as ryanodine receptors (RyR), SR Ca-ATPase (SERCa) and Inositol 1,4,5-triphosphate ( $\mathrm{IP}_{3}$ )-induced $\mathrm{Ca}$ release channel thus increasing calcium entry into cardiomyocytes and triggering widespread cellular injury [90]. Gene expression of most antioxidant enzymes, such as superoxide dismutase (SOD), glutathione peroxidase (Gpx), catalase or hemeoxygenase-1 (HO-1) is inducible under inflammation, or other stressful conditions as a protective mechanism to clear ROS. There are three SOD isoforms that catalyze the dismutation of superoxide anion $\mathrm{O}_{2}$ thereby attenuating oxidative stress in various cellular compartments [91].

Antioxidant gene therapy offers promise in combating MI/R injury in the heart [91] and has been primarily utilized prior to the MI/R insult to increase levels of tissue anti oxidants so that they are available for cardioprotection at the time of MI/R. Gene therapy to induce overexpression of extracellular superoxide dismutase (Ec SOD) leads to decreased stunning [92] and decreased infarct size following MI/R injury [93,94]. The intracellular counterparts (Mn-SOD and $\mathrm{Cu} / \mathrm{Zn}-\mathrm{SOD}$ ) have been proven to decrease apoptosis, decrease infarct size and to delay induction of NF-kappaB [95]. Mn-SOD and eNOS genes when delivered together lead to decreased infarct size following MI/R as well [96]. Human hemoxygenase-1 (hHO-1) gene therapy administered 6-8 weeks prior to MI/R leads to decreased mortality at one year [97], decreased lipid peroxidation [98] and reduction in ventricular thinning [99].

HO-1 has also been suggested to induce formation of VEGF [100]. Hypoxia-regulated gene therapies have been designed to circumvent the problem of excess expression under normoxic conditions. One such therapy involves plasmid mediated hHO-1 gene transfer. Gene therapy in this case pre-emptively administered results in gene expression following hypoxia and subsequent decrease in infarct size, lipid peroxidation and attenuated remodeling [101].

Thioredoxins (Trx) are proteins that act as potent antioxidants in mammalian cells and provide protection against oxidative stress by decreased p38MAPK signaling [102] and decreased superoxide anion generation [103]. Trx-1 gene therapy administered post MI leads to angiogenesis, decreased apoptosis, reduced ventricular remodeling, and improved ejection fraction in diabetic rats [104]. Most gene therapy using anti-oxidant genes has been in the form of preemptive therapies where protein expression has been enhanced by the time MI occurred. In reality this therapy may not be practical in an acute MI setting but may be beneficial as a preventive strategy in patients who have known coronary artery disease and other cardiovascular disease states to protect them from future ischemic events.

\section{Endothelial Nitric Oxide Synthase (eNOS) Gene Therapy}

Nitric oxide (NO) is a signaling molecule with multiple protective functions in the heart especially during I/R injury [105]. It is synthesized from L-arginine by the action of three 
isoforms of nitric oxide synthase in mammals of which endothelial nitric oxide synthase (eNOS) is primarily responsible for cardioprotection. Adenovirus mediated human eNOS gene therapy administered in animals four days before MI leads to decreased infarct size, increased capillary density, improved contractility and decreased MAPK phosphorylation $[106,107]$. Gene transfer of eNOS after MI in rats leads to decreased fibrosis, lower levels of TGF- $\beta 1$, p27 and NF-kappaB protein levels and lesser apoptosis [108]. eNOS S1177D (an activated form of eNOS) has been utilized in liposome based gene delivery and results in decreased NF-kappaB activation and decreased polymorphonuclear cell infiltrate after MI [109]. In the same study the authors concluded that VEGF gene transfection affords cardioprotection in MI/R via phosphorylation of eNOS. Inducible nitric oxide synthase (iNOS), viewed traditionally as a deleterious enzyme, given pre-emptively before MI/R leads to decrease in infarct size [110], induction of COX-2 [111], and upregulation of HO-1 mRNA [112]. Thus NOS gene therapy has the capability of inducing angiogenesis, reducing apoptosis and decreasing inflammation after an ischemic insult to the heart.

\section{Gene Therapy and Proteins Involved in Apoptosis}

Heat shock proteins (HSPs) function as molecular chaperones responsible for protein folding, intracellular trafficking of proteins, and modification of proteins denatured by heat or other stresses. HSP 70 gene delivered in myocardium of rabbits prior to MI decreases infarct size following MI [113]. HSP 20 also given prior to MI/R injury reduces apoptosis, improves LV end systolic and end diastolic pressures and decreases infarct size [114]. HSP 72 gene transfer during rat MI/R decreases apoptosis, improves respiratory index, increases Mn SOD activity, increases Bcl-2 level and inhibits upregulation of caspase-3 [115]. Hence gene therapy of the ischemic heart with HSPs reduces apoptosis and has proven to be cardioprotective after MI in animal models.

Mitogen-activated protein kinase (MAPK) cascade consists of extracellular signal-regulated protein kinase (ERK), p38 kinase and c-jun N-terminal protein kinase (JNK). MAPK is a critical regulator of cell survival and death. Adverse postinfarction remodeling is associated with reduced p38 signaling. Transfection of wild-type (WT) p38 kinase combined with that of active MAP kinase kinase $3 b$ (which is an upstream activator of p38 kinase) during rat $\mathrm{MI} / \mathrm{R}$ results in reduction in infarct size, lesser apoptosis, increased capillary density, decreased fibrosis and improvement in ejection fraction [116].

Protein kinases are important regulators of angiogenesis [117]. Troponin I type 3 interacting kinase (TNNI3K) is a mitogen activated protein (MAP) kinase, which apart from being angiogenic, is also myogenic. Gene transfection of P19CL6 pluripotent progenitor cells with TNNI3K gene and administration in mice after MI leads to reduced MI induced injury, inhibits remodeling and induces myogenesis in the ischemic heart [118]. Thus targeting the MAPK/p38 signaling cascade by gene therapy of ischemic heart leads to reduced apoptosis and promotes angiogenesis as well.

Insulin like growth factor -1 (IGF-1) is produced primarily by liver as an endocrine hormone but is produced in target tissues in a paracrine/autocrine fashion. Production is stimulated by action of growth hormone and inhibited by malnutrition and growth hormone insensitivity. IGF-1 while inhibiting programmed cell death, activates AKT signaling pathway and stimulates growth and proliferation of cells. IGF-1 overexpressing mesenchymal stem cells help accelerate bone marrow stem cell mobilization via activation of SDF-1alpha/CXCR4 signaling which leads to growth and proliferation of cells and decreased apoptosis thereby promoting myocardial repair and improving fractional shortening and ejection fraction in a rat MI model [119]. Hence gene therapy with IGF-1 and SDF-1alpha reduces adverse remodeling and is cardioprotective. 


\section{Gene Therapy for other proteins involved in Apoptosis}

Tumor Necrosis Factor (TNF) is a cytokine produced by activated macrophages and acts via the TNF receptor triggering apoptosis, inflammation and suppression of tumorigenesis. Soluble TNF-alpha receptor 1 (sTNFR1) has the ability to act as an antagonist to TNF. sTNFR1 gene therapy after MI in mice reduces infract size and improves cardiac function [120].

Leukemia inhibitory factor (LIF) is an interleukin 6-related cytokine that regulates differentiation, growth and regeneration, both during embryogenesis and in adult tissues $[121,122]$ including the myocardium $[123,124]$. Gene delivery of LIF and subsequent overexpression leads to decreased fibrosis, increased LV thickness, fewer apoptotic nuclei in the border zone of ischemia, decreased ventricular dilatation and hence preservation of rat myocardium post MI [125].

Sonic hedgehog homolog (Shh) is a protein involved in mammalian hedgehog signaling pathway that plays a key role in organogenesis. Gene transfer of naked DNA encoding the human Shh gene in myocardial ischemia has been shown to preserve ventricular function by enhancing neovascularization, reducing apoptosis and reducing fibrosis $[79,126]$.

The kallikrein-kinin system is a system of proteins that controls blood pressure and induces pain and inflammation. The system is mediated through bradykinin and kallidin that are liberated from their precursor kininogens by the protease action of kallikreins. Kallikrein gene delivery has been shown to increase capillary density, decrease apoptosis, decrease endothelial dysfunction and preserve cardiac output post MI in rats [127].

Cluster of Differentiation 151 (CD151) is a gene encoding for a cell surface protein that plays a role in cell development, growth, activation and cell motility. CD151 gene delivery after myocardial infarction promotes neovascularization and improves cardiac function in pigs [128] and rats[129].

The Akt family of protein kinases is involved in cell survival pathways and its members inhibit apoptosis. Akt1 has also been implicated in angiogenesis. Adenovirus-mediated Akt gene transfer pre emptively in rat hearts limits infarct size following ischemia-reperfusion injury [130]. Adenoviral gene transfer of Akt in wild-type rat hearts enhances myocardial contractility and intracellular calcium handling [131]. Hence, Akt gene therapy has potential to be used in heart failure as well.

Bcl-2 protein, functioning in the mitochondria is anti-apoptotic by counteracting Bax and Bak and inhibiting cytochrome $\mathrm{c}$ release. Overexpression of $\mathrm{Bcl}-2$ promotes cell survival and inhibits cell death [132]. Overexpression of human Bcl-2 in ischemia/reperfusion injury in a transgenic mouse model over expressing the $\mathrm{Bcl} 2 \mathrm{cDNA}$ led to reduction in infarct size and improvement in ejection fraction over wild type controls [133]. Gene therapy with Bcl2 gene in rabbits after MI/R shows reduced apoptosis, lesser ventricular dilatation and decreased wall thinning [134].

Apoptosis repressor is another protein utilized as anti apoptotic therapy in ischemic heart disease. Post ischemic cardiomyopathy and remodeling following MI/R injury in rabbits is delayed with viral gene transfer of an apoptosis repressor with caspase recruitment domain, which results in inhibition of apoptosis, lesser LV dilatation, preserved EF [135].

Cardiotrophin-1 (CT-1), a member of the interluekin-6 family of cytokines protects the heart against ischemia/reperfusion injury and plays a substantial role in cardiac repair and hypertrophy $[136,137]$. Gene therapy of CT-1 in mouse hearts after MI results in decreased 
apoptosis, decreased infarct size, decreased caspase-3 activation and improved ventricular pressure indices [138].

Sphingosine kinase (SPHK) is a lipid kinase involved in sphingolipid metabolism. SPHK 1 leads to formation of sphingosine-1-phosphate (S1P), which, acting through its receptor S1P1 activates eNOS, induces endothelial cell chemotaxis and maintains vascular integrity [139]. SPHK1 gene therapy in rats after MI preserves systolic and diastolic functions of the heart and leads to improved peak contraction velocity [140].

Thus gene therapy overexpressing TNF, LIF, Shh protein, Kallikrein, CD151, Akt, Bcl-2, apoptosis repressor gene, CT-1 and SPHK improve various aspects of pathophysiology associated with ischemic heart disease.

\section{Clinical Trials on Gene Therapy for Ischemic Heart Disease}

Controlled clinical trials for gene therapy in ischemic heart disease that have been published include: VEGF-165, VEGF-121, VEGF-C and FGF-4. Gene therapy with VEGF-165 has been proven successful in the Kuopio Angiogenesis Trial (KAT trial) and encouraging in the EUROINJECT trial. In the KAT trial, adenovirus mediated VEGF-A165 gene therapy when administered by intracoronary injection in patients with class $2-3$ angina undergoing PTCA showed improvement in coronary perfusion with no difference in the rates of vascular stenosis [141]. The study followed patients for 8 years and demonstrated its safety and efficacy in patients with coronary artery disease [142]. VEGF-A165 gene therapy administered intramyocardially in plasmid form in patients with Canadian class 3-4 angina with no other therapeutic options showed little improvement in perfusion defects after 3 months in the EUROINJECT trial [143]. However, subsequent analysis revealed improvement in wall motion and LV function suggesting that these benefits may be mediated by factors others than an increase in angiogenesis [144]. VEGF-165 plasmid mediated gene therapy followed by injection of G-CSF to mobilize stem cells has been tried in 16 patients who failed conventional therapeutic strategies [145]. Gene therapy in this small trial showed no improvements in myocardial stress perfusion and may have been due to inadequate homing of stem cells at zones of infarction. Other factors responsible for the lack of response may have been poor timing of G-CGF injections or inadequacy of SPECT scanning in demonstrating minor changes in regional perfusion. Similarly, the NORTHERN trial, involving VEGF-A165 gene therapy through transfection with naked plasmid DNA did not show any improvement in perfusion and exercise time in class 3-4 chronic angina [146]. Interestingly, both the EUROINJECT and NORTHERN trials clearly demonstrated that gene therapy was safe and despite the lack of clear benefit was not detrimental and did not worsen clinical outcomes. Since naked plasmid DNA was used in both these studies, low gene transfection could be one of the reasons why these trials did not lead to significant clinical improvement and future trials may require the use of viral vector mediated gene transfer.

Several other clinical trials have demonstrated symptomatic improvements with gene therapy. Preliminary results with VEGF-121 and VEGF-2 have been promising. In the REVASC trial, VEGF-121 gene therapy through adenoviruses, administered via intramyocardial injection following a mini-thoracotomy in patients with severe refractory angina not amenable to standard medical therapy resulted in improved exercise time before electrocardiographic changes of ischemia, increased total exercise time and improved anginal symptoms at 26 weeks of follow up [147]. Plasmid VEGF-2 (VEGF-C) therapy in patients with chronic class 3-4 angina was safe and resulted in improvement of symptoms in initial pilot studies [148] and in long term follow up [149]. 
In the AGENT (Angiogenic GENe Therapy) [150] and AGENT 2 trials [151], FGF-4 gene therapy administered to patients with class $2-3$ angina resulted in improvement in exercise time at 4 weeks. But larger trials the AGENT -3 and -4 , trials of a low and high dose of Ad5FGF-4 for chronic angina involving 532 patients in a randomized, double-blind, placebo-controlled fashion in multiple countries were halted when an interim analysis of the AGENT-3 trial indicated that the primary end point change from baseline in total ETT time at 12 weeks did not reach significance. Sub-group analysis in these trials have however shown significantly improved exercise time in women and may have been due to increased severity of CAD in women compared to men. Therefore gender based differences in response to gene therapy is an important factor which may need to be investigated further to appropriately identify target populations that would benefit from these therapies [152]. There is an ongoing bFGF gene therapy clinical trial in women with ischemic heart disease (AWARE trial), for the same reason. A gene therapy trial with VEGF-165/bFGF bicistronic plasmid been completed but the results are unavailable. This therapy might prove superior since a double treatment strategy with the use of two angiogenic factors is being employed. If successful this approach would demonstrate a change in myocardial perfusion on SPECT scans as the primary outcome measure.

\section{Current Problems Limiting Application of Gene Therapy}

As with most experimental therapies, safety of gene therapy for ischemic heart disease is of paramount importance. Though clinical trials have shown short-term safety, long-term surveillance over a period of decades is lacking. The question still remains as to which therapy benefits what subpopulation of patients. Inclusion of a wide selection of patients in studies over time may lead to improvement in subgroups of patients if not the entire population. Confounding factors such as use of concurrent medications and concurrent medical conditions lead to difficulty in standardizing groups of patients. Objective end points of assessment need to be used uniformly as exercise testing may be subjective and is victim to high variability in the same patient on different days. Frequency of testing for objective improvements may need to be ramped up as the effects of therapeutic gene may have abated at the time of a single test. Another surprising factor that confounded results of clinical trails was a strong placebo effect. This might be minimized when objective and not subjective end points are used when assessing outcomes. Drug related issues such as the dose, gene transfection efficiency, pharmacokinetics and pharmacodynamics of individual therapies are valid as these may differ in different populations of patients. Also costeffectiveness analysis has to be considered, as production of gene therapy vectors itself is cumbersome requiring specialized equipment and personnel and administration of gene therapy is invasive in nature. Besides, specific gene therapy may not compare favorably to available pharmacological agents in use to treat ischemic heart disease in terms of cost: benefit ratio. It is possible that extensive use of small animals for preclinical research may have led to excessive enthusiasm too early. Gene therapy testing on larger animals may provide a better insight into the true efficacy of specific therapies.

\section{Conclusion and Future Directions}

The vast amount of preclinical research attests to the enormous interest currently shown by researchers and clinicians in developing gene therapies for ischemic heart disease. Several improvements in gene therapy technology have improved efficacy and led to marked success in animal models of ischemic heart disease. Importantly, these improvements will likely augment the successes of clinical trials on gene therapy that have already demonstrated an excellent safety profile in this setting. 
One such improvement is the design of novel gene constructs used to regulate gene expression that lead to controllable protein levels in target tissues [153] [154]. Another improvement is the inclusion of tissue specific promoters in some gene constructs which promotes therapeutic gene expression restricted to target tissues and limits gene expression in non target tissues [155] [156].

Use of specialized catheters (such as the NOGA catheter) and improved gene transfection techniques are making gene therapy more efficacious. Ultrasound-targeted microbubble destruction is one such technique that employs myocardial contrast echocardiography to deliver therapeutic plasmids to the myocardium. Plasmids bind to microbubbles, which are then delivered to the myocardium possibly after endothelial injury induced by the microbubbles [157]. Novel bubble liposomes which are smaller than conventional microbubbles have been developed, and could prove better than microbubbles for gene transfection [158].

In a few patients, understandably, infusion of viral vectors may be of concern due to fear of infectious disease from infused viral vectors or to insertional mutagenesis. Several non-viral vectors with good transfection efficiency such as biodegradable lipid modified polymers [159] and nanoparticles [160] have been developed in the recent years. Despite the promising results seen in clinical trials and good initial safety profile there are several challenges that need to be overcome before gene therapy becomes a mainstream therapy for ischemic heart disease. With the current pace of rigorous preclinical research to delineate various targets in the diseased pathways, constantly improving gene transfer techniques, design of novel regulated gene expression mechanisms and, improving safety profiles, gene therapy may soon become an accepted treatment for ischemic heart disease in man.

\section{References}

1. Thom T, Haase N, Rosamond W, Howard VJ, Rumsfeld J, Manolio T, et al. Heart disease and stroke statistics--2006 update: a report from the American Heart Association Statistics Committee and Stroke Statistics Subcommittee. Circulation. 2006 Feb 14; 113(6):e85-151. [PubMed: 16407573]

2. Suzuki K, Murtuza B, Smolenski RT, Sammut IA, Suzuki N, Kaneda Y, et al. Cell transplantation for the treatment of acute myocardial infarction using vascular endothelial growth factor-expressing skeletal myoblasts. Circulation. 2001 Sep 18; 104(12 Suppl 1):I207-12. [PubMed: 11568057]

3. Askari A, Unzek S, Goldman CK, Ellis SG, Thomas JD, DiCorleto PE, et al. Cellular, but not direct, adenoviral delivery of vascular endothelial growth factor results in improved left ventricular function and neovascularization in dilated ischemic cardiomyopathy. J Am Coll Cardiol. 2004 May 19; 43(10):1908-14. [PubMed: 15145120]

4. Ye L, Haider H, Jiang S, Tan RS, Toh WC, Ge R, et al. Angiopoietin-1 for myocardial angiogenesis: a comparison between delivery strategies. Eur J Heart Fail. 2007 May; 9(5):458-65. [PubMed: 17188570]

5. Ferrara N. Vascular endothelial growth factor: molecular and biological aspects. Curr Top Microbiol Immunol. 1999; 237:1-30. [PubMed: 9893343]

6. Zhao T, Zhao W, Chen Y, Ahokas RA, Sun Y. Vascular Endothelial Growth Factor (VEGF)-A: Role on Cardiac Angiogenesis following Myocardial Infarction. Microvasc Res. 2010 Mar 31.

7. Tammela T, Enholm B, Alitalo K, Paavonen K. The biology of vascular endothelial growth factors. Cardiovasc Res. 2005 Feb 15; 65(3):550-63. [PubMed: 15664381]

8. Bellomo D, Headrick JP, Silins GU, Paterson CA, Thomas PS, Gartside M, et al. Mice lacking the vascular endothelial growth factor-B gene (Vegfb) have smaller hearts, dysfunctional coronary vasculature, and impaired recovery from cardiac ischemia. Circ Res. 2000 Feb 4; 86(2):E29-35. [PubMed: 10666423] 
9. Olofsson B, Korpelainen E, Pepper MS, Mandriota SJ, Aase K, Kumar V, et al. Vascular endothelial growth factor B (VEGF-B) binds to VEGF receptor-1 and regulates plasminogen activator activity in endothelial cells. Proc Natl Acad Sci U S A. 1998 Sep 29; 95(20):11709-14. [PubMed: 9751730]

10. Breier G, Clauss M, Risau W. Coordinate expression of vascular endothelial growth factor receptor-1 (flt-1) and its ligand suggests a paracrine regulation of murine vascular development. Dev Dyn. 1995 Nov; 204(3):228-39. [PubMed: 8573716]

11. Arany Z, Foo SY, Ma Y, Ruas JL, Bommi-Reddy A, Girnun G, et al. HIF-independent regulation of VEGF and angiogenesis by the transcriptional coactivator PGC-1alpha. Nature. 2008 Feb 21; 451(7181):1008-12. [PubMed: 18288196]

12. Ferrara N, Carver-Moore K, Chen H, Dowd M, Lu L, O'Shea KS, et al. Heterozygous embryonic lethality induced by targeted inactivation of the VEGF gene. Nature. 1996 Apr 4; 380(6573):439_ 42. [PubMed: 8602242]

13. Rissanen TT, Yla-Herttuala S. Current status of cardiovascular gene therapy. Mol Ther. 2007 Jul; 15(7):1233-47. [PubMed: 17505481]

14. Hao X, Mansson-Broberg A, Grinnemo KH, Siddiqui AJ, Dellgren G, Brodin LA, et al. Myocardial angiogenesis after plasmid or adenoviral VEGF-A(165) gene transfer in rat myocardial infarction model. Cardiovasc Res. 2007 Feb 1; 73(3):481-7. [PubMed: 17134685]

15. Ruixing Y, Jiaquan L, Jie C, Dezhai Y. Intravenous administration of vascular endothelial growth factor improves cardiac performance and inhibits cardiomyocyte apoptosis. Growth Factors. 2006 Sep; 24(3):209-17. [PubMed: 17079204]

16. Bull DA, Bailey SH, Rentz JJ, Zebrack JS, Lee M, Litwin SE, et al. Effect of Terplex/VEGF-165 gene therapy on left ventricular function and structure following myocardial infarction. VEGF gene therapy for myocardial infarction. J Control Release. 2003 Dec 5; 93(2):175-81. [PubMed: 14636723]

17. Tio RA, Tkebuchava T, Scheuermann TH, Lebherz C, Magner M, Kearny M, et al. Intramyocardial gene therapy with naked DNA encoding vascular endothelial growth factor improves collateral flow to ischemic myocardium. Hum Gene Ther. 1999 Dec 10; 10(18):295360. [PubMed: 10609656]

18. Jacquier A, Higgins CB, Martin AJ, Do L, Saloner D, Saeed M. Injection of adeno-associated viral vector encoding vascular endothelial growth factor gene in infarcted swine myocardium: MR measurements of left ventricular function and strain. Radiology. 2007 Oct; 245(1):196-205. [PubMed: 17885189]

19. Choi JS, Kim KB, Han W, Kim DS, Park JS, Lee JJ, et al. Efficacy of therapeutic angiogenesis by intramyocardial injection of pCK-VEGF165 in pigs. Ann Thorac Surg. 2006 Aug; 82(2):679-86. [PubMed: 16863784]

20. Zhang D, Gai L, Fan R, Dong W, Wen Y. Efficacy and safety of therapeutic angiogenesis from direct myocardial administration of an adenoviral vector expressing vascular endothelial growth factor 165. Chin Med J (Engl). 2002 May; 115(5):643-8. [PubMed: 12133527]

21. Ferrarini M, Arsic N, Recchia FA, Zentilin L, Zacchigna S, Xu X, et al. Adeno-associated virusmediated transduction of VEGF165 improves cardiac tissue viability and functional recovery after permanent coronary occlusion in conscious dogs. Circ Res. 2006 Apr 14; 98(7):954-61. [PubMed: 16543500]

22. Lee LY, Patel SR, Hackett NR, Mack CA, Polce DR, El-Sawy T, et al. Focal angiogen therapy using intramyocardial delivery of an adenovirus vector coding for vascular endothelial growth factor 121. Ann Thorac Surg. 2000 Jan; 69(1):14-23. discussion -4. [PubMed: 10654479]

23. Mack CA, Patel SR, Schwarz EA, Zanzonico P, Hahn RT, Ilercil A, et al. Biologic bypass with the use of adenovirus-mediated gene transfer of the complementary deoxyribonucleic acid for vascular endothelial growth factor 121 improves myocardial perfusion and function in the ischemic porcine heart. J Thorac Cardiovasc Surg. 1998 Jan; 115(1):168-76. discussion 76-7. [PubMed: 9451061]

24. Heilmann CA, Attmann T, von Samson P, Gobel H, Marme D, Beyersdorf F, et al. Transmyocardial laser revascularization combined with vascular endothelial growth factor 121 (VEGF121) gene therapy for chronic myocardial ischemia--do the effects really add up? Eur J Cardiothorac Surg. 2003 Jan; 23(1):74-80. [PubMed: 12493508] 
25. Sayeed-Shah U, Mann MJ, Martin J, Grachev S, Reimold S, Laurence R, et al. Complete reversal of ischemic wall motion abnormalities by combined use of gene therapy with transmyocardial laser revascularization. J Thorac Cardiovasc Surg. 1998 Nov; 116(5):763-9. [PubMed: 9806383]

26. Hagberg CE, Falkevall A, Wang X, Larsson E, Huusko J, Nilsson I, et al. Vascular endothelial growth factor B controls endothelial fatty acid uptake. Nature. 2010 Mar 14.

27. Li X, Tjwa M, Van Hove I, Enholm B, Neven E, Paavonen K, et al. Reevaluation of the role of VEGF-B suggests a restricted role in the revascularization of the ischemic myocardium. Arterioscler Thromb Vasc Biol. 2008 Sep; 28(9):1614-20. [PubMed: 18511699]

28. Lahteenvuo JE, Lahteenvuo MT, Kivela A, Rosenlew C, Falkevall A, Klar J, et al. Vascular endothelial growth factor-B induces myocardium-specific angiogenesis and arteriogenesis via vascular endothelial growth factor receptor-1- and neuropilin receptor-1-dependent mechanisms. Circulation. 2009 Feb 17; 119(6):845-56. [PubMed: 19188502]

29. Patila T, Ikonen T, Rutanen J, Ahonen A, Lommi J, Lappalainen K, et al. Vascular endothelial growth factor $\mathrm{C}$-induced collateral formation in a model of myocardial ischemia. J Heart Lung Transplant. 2006 Feb; 25(2):206-13. [PubMed: 16446222]

30. Rutanen J, Rissanen TT, Markkanen JE, Gruchala M, Silvennoinen P, Kivela A, et al. Adenoviral catheter-mediated intramyocardial gene transfer using the mature form of vascular endothelial growth factor-D induces transmural angiogenesis in porcine heart. Circulation. 2004 Mar 2; 109(8):1029-35. [PubMed: 14967735]

31. Celletti FL, Waugh JM, Amabile PG, Brendolan A, Hilfiker PR, Dake MD. Vascular endothelial growth factor enhances atherosclerotic plaque progression. Nat Med. 2001 Apr; 7(4):425-9. [PubMed: 11283668]

32. Lee RJ, Springer ML, Blanco-Bose WE, Shaw R, Ursell PC, Blau HM. VEGF gene delivery to myocardium: deleterious effects of unregulated expression. Circulation. 2000 Aug 22; 102(8):898901. [PubMed: 10952959]

33. Schwarz ER, Speakman MT, Patterson M, Hale SS, Isner JM, Kedes LH, et al. Evaluation of the effects of intramyocardial injection of DNA expressing vascular endothelial growth factor (VEGF) in a myocardial infarction model in the rat--angiogenesis and angioma formation. J Am Coll Cardiol. 2000 Apr; 35(5):1323-30. [PubMed: 10758976]

34. Lee M, Rentz J, Bikram M, Han S, Bull DA, Kim SW. Hypoxia-inducible VEGF gene delivery to ischemic myocardium using water-soluble lipopolymer. Gene Ther. 2003 Sep; 10(18):1535-42. [PubMed: 12907944]

35. Su H, Arakawa-Hoyt J, Kan YW. Adeno-associated viral vector-mediated hypoxia response element-regulated gene expression in mouse ischemic heart model. Proc Natl Acad Sci U S A. 2002 Jul 9; 99(14):9480-5. [PubMed: 12084814]

36. Yockman JW, Choi D, Whitten MG, Chang CW, Kastenmeier A, Erickson H, et al. Polymeric gene delivery of ischemia-inducible VEGF significantly attenuates infarct size and apoptosis following myocardial infarct. Gene Ther. 2009 Jan; 16(1):127-35. [PubMed: 18784748]

37. Dong H, Wang Q, Zhang Y, Jiang B, Xu X, Zhang Z. Angiogenesis induced by hVEGF165 gene controlled by hypoxic response elements in rabbit ischemia myocardium. Exp Biol Med (Maywood). 2009 Dec; 234(12):1417-24. [PubMed: 19934363]

38. Morishita R, Aoki M, Yo Y, Ogihara T. Hepatocyte growth factor as cardiovascular hormone: role of HGF in the pathogenesis of cardiovascular disease. Endocr J. 2002 Jun; 49(3):273-84. [PubMed: 12201209]

39. Aoki M, Morishita R, Taniyama Y, Kida I, Moriguchi A, Matsumoto K, et al. Angiogenesis induced by hepatocyte growth factor in non-infarcted myocardium and infarcted myocardium: upregulation of essential transcription factor for angiogenesis, ets. Gene Ther. 2000 Mar; 7(5):41727. [PubMed: 10694824]

40. Funatsu T, Sawa Y, Ohtake S, Takahashi T, Matsumiya G, Matsuura N, et al. Therapeutic angiogenesis in the ischemic canine heart induced by myocardial injection of naked complementary DNA plasmid encoding hepatocyte growth factor. J Thorac Cardiovasc Surg. 2002 Dec; 124(6):1099-105. [PubMed: 12447174] 
41. Wang W, Yang ZJ, Ma DC, Wang LS, Xu SL, Zhang YR, et al. Induction of collateral artery growth and improvement of post-infarct heart function by hepatocyte growth factor gene transfer. Acta Pharmacol Sin. 2006 May; 27(5):555-60. [PubMed: 16626510]

42. Li Y, Takemura G, Kosai K, Yuge K, Nagano S, Esaki M, et al. Postinfarction treatment with an adenoviral vector expressing hepatocyte growth factor relieves chronic left ventricular remodeling and dysfunction in mice. Circulation. 2003 May 20; 107(19):2499-506. [PubMed: 12695295]

43. Jin H, Wyss JM, Yang R, Schwall R. The therapeutic potential of hepatocyte growth factor for myocardial infarction and heart failure. Curr Pharm Des. 2004; 10(20):2525-33. [PubMed: 15320761]

44. Jayasankar V, Woo YJ, Bish LT, Pirolli TJ, Chatterjee S, Berry MF, et al. Gene transfer of hepatocyte growth factor attenuates postinfarction heart failure. Circulation. 2003 Sep 9; 108(Suppl 1):II230-6. [PubMed: 12970238]

45. Yang ZJ, Chen B, Sheng Z, Zhang DG, Jia EZ, Wang W, et al. Improvement of heart function in postinfarct heart failure swine models after hepatocyte growth factor gene transfer: comparison of low-, medium- and high-dose groups. Mol Biol Rep. 2010 Apr; 37(4):2075-81. [PubMed: 19680789]

46. Yang Z, Wang W, Ma D, Zhang Y, Wang L, Xu S, et al. Recruitment of stem cells by hepatocyte growth factor via intracoronary gene transfection in the postinfarction heart failure. Sci China $\mathrm{C}$ Life Sci. 2007 Dec; 50(6):748-52. [PubMed: 17973092]

47. Ahmet I, Sawa Y, Iwata K, Matsuda H. Gene transfection of hepatocyte growth factor attenuates cardiac remodeling in the canine heart: A novel gene therapy for cardiomyopathy. J Thorac Cardiovasc Surg. 2002 Nov; 124(5):957-63. [PubMed: 12407379]

48. Taniyama Y, Morishita R, Aoki M, Hiraoka K, Yamasaki K, Hashiya N, et al. Angiogenesis and antifibrotic action by hepatocyte growth factor in cardiomyopathy. Hypertension. $2002 \mathrm{Jul}$; 40(1): 47-53. [PubMed: 12105137]

49. Cho KR, Choi JS, Hahn W, Kim DS, Park JS, Lee DS, et al. Therapeutic angiogenesis using naked DNA expressing two isoforms of the hepatocyte growth factor in a porcine acute myocardial infarction model. Eur J Cardiothorac Surg. 2008 Oct; 34(4):857-63. [PubMed: 18620865]

50. Ahmet I, Sawa Y, Yamaguchi T, Matsuda H. Gene transfer of hepatocyte growth factor improves angiogenesis and function of chronic ischemic myocardium in canine heart. Ann Thorac Surg. 2003 Apr; 75(4):1283-7. [PubMed: 12683576]

51. Kondo I, Ohmori K, Oshita A, Takeuchi H, Fuke S, Shinomiya K, et al. Treatment of acute myocardial infarction by hepatocyte growth factor gene transfer: the first demonstration of myocardial transfer of a "functional" gene using ultrasonic microbubble destruction. J Am Coll Cardiol. 2004 Aug 4; 44(3):644-53. [PubMed: 15358035]

52. Ornitz DM, Itoh N. Fibroblast growth factors. Genome Biol. 2001; 2(3):REVIEWS3005. [PubMed: 11276432]

53. Khurana R, Simons M. Insights from angiogenesis trials using fibroblast growth factor for advanced arteriosclerotic disease. Trends Cardiovasc Med. 2003 Apr; 13(3):116-22. [PubMed: 12691676]

54. Horvath KA, Doukas J, Lu CY, Belkind N, Greene R, Pierce GF, et al. Myocardial functional recovery after fibroblast growth factor 2 gene therapy as assessed by echocardiography and magnetic resonance imaging. Ann Thorac Surg. 2002 Aug; 74(2):481-6. discussion 7. [PubMed: 12173832]

55. Heilmann C, von Samson P, Schlegel K, Attmann T, von Specht BU, Beyersdorf F, et al. Comparison of protein with DNA therapy for chronic myocardial ischemia using fibroblast growth factor-2. Eur J Cardiothorac Surg. 2002 Dec; 22(6):957-64. [PubMed: 12467820]

56. Post MJ, Sato K, Murakami M, Bao J, Tirziu D, Pearlman JD, et al. Adenoviral PR39 improves blood flow and myocardial function in a pig model of chronic myocardial ischemia by enhancing collateral formation. Am J Physiol Regul Integr Comp Physiol. 2006 Mar; 290(3):R494-500. [PubMed: 16254127]

57. Gao MH, Lai NC, McKirnan MD, Roth DA, Rubanyi GM, Dalton N, et al. Increased regional function and perfusion after intracoronary delivery of adenovirus encoding fibroblast growth factor 4: report of preclinical data. Hum Gene Ther. 2004 Jun; 15(6):574-87. [PubMed: 15212716] 
58. Giordano FJ, Ping P, McKirnan MD, Nozaki S, DeMaria AN, Dillmann WH, et al. Intracoronary gene transfer of fibroblast growth factor-5 increases blood flow and contractile function in an ischemic region of the heart. Nat Med. 1996 May; 2(5):534-9. [PubMed: 8616711]

59. Suzuki G, Lee TC, Fallavollita JA, Canty JM Jr. Adenoviral gene transfer of FGF-5 to hibernating myocardium improves function and stimulates myocytes to hypertrophy and reenter the cell cycle. Circ Res. 2005 Apr 15; 96(7):767-75. [PubMed: 15761196]

60. Atkins BZ, Hueman MT, Meuchel J, Hutcheson KA, Glower DD, Taylor DA. Cellular cardiomyoplasty improves diastolic properties of injured heart. J Surg Res. 1999 Aug; 85(2):23442. [PubMed: 10423324]

61. Hattan N, Warltier D, Gu W, Kolz C, Chilian WM, Weihrauch D. Autologous vascular smooth muscle cell-based myocardial gene therapy to induce coronary collateral growth. Am J Physiol Heart Circ Physiol. 2004 Aug; 287(2):H488-93. [PubMed: 15277192]

62. Ninomiya M, Koyama H, Miyata T, Hamada H, Miyatake S, Shigematsu H, et al. Ex vivo gene transfer of basic fibroblast growth factor improves cardiac function and blood flow in a swine chronic myocardial ischemia model. Gene Ther. 2003 Jul; 10(14):1152-60. [PubMed: 12833124]

63. Haider H, Ye L, Jiang S, Ge R, Law PK, Chua T, et al. Angiomyogenesis for cardiac repair using human myoblasts as carriers of human vascular endothelial growth factor. J Mol Med. 2004 Aug; 82(8):539-49. [PubMed: 15175859]

64. Ye L, Haider H, Tan R, Toh W, Law PK, Tan W, et al. Transplantation of nanoparticle transfected skeletal myoblasts overexpressing vascular endothelial growth factor-165 for cardiac repair. Circulation. 2007 Sep 11; 116(11 Suppl):I113-20. [PubMed: 17846290]

65. Yau TM, Kim C, Ng D, Li G, Zhang Y, Weisel RD, et al. Increasing transplanted cell survival with cell-based angiogenic gene therapy. Ann Thorac Surg. 2005 Nov; 80(5):1779-86. [PubMed: 16242455]

66. Elmadbouh I, Haider H, Jiang S, Idris NM, Lu G, Ashraf M. Ex vivo delivered stromal cell-derived factor-1alpha promotes stem cell homing and induces angiomyogenesis in the infarcted myocardium. J Mol Cell Cardiol. 2007 Apr; 42(4):792-803. [PubMed: 17350033]

67. Azarnoush K, Maurel A, Sebbah L, Carrion C, Bissery A, Mandet C, et al. Enhancement of the functional benefits of skeletal myoblast transplantation by means of coadministration of hypoxiainducible factor 1alpha. J Thorac Cardiovasc Surg. 2005 Jul; 130(1):173-9. [PubMed: 15999059]

68. Pittenger MF, Martin BJ. Mesenchymal stem cells and their potential as cardiac therapeutics. Circ Res. 2004 Jul 9; 95(1):9-20. [PubMed: 15242981]

69. Matsumoto R, Omura T, Yoshiyama M, Hayashi T, Inamoto S, Koh KR, et al. Vascular endothelial growth factor-expressing mesenchymal stem cell transplantation for the treatment of acute myocardial infarction. Arterioscler Thromb Vasc Biol. 2005 Jun; 25(6):1168-73. [PubMed: 15831811]

70. Chen SY, Wang F, Yan XY, Zhou Q, Ling Q, Ling JX, et al. Autologous transplantation of EPCs encoding FGF1 gene promotes neovascularization in a porcine model of chronic myocardial ischemia. Int J Cardiol. 2009 Jun 26; 135(2):223-32. [PubMed: 19181401]

71. Miyagawa S, Sawa Y, Taketani S, Kawaguchi N, Nakamura T, Matsuura N, et al. Myocardial regeneration therapy for heart failure: hepatocyte growth factor enhances the effect of cellular cardiomyoplasty. Circulation. 2002 May 28; 105(21):2556-61. [PubMed: 12034665]

72. Lim SY, Kim YS, Ahn Y, Jeong MH, Hong MH, Joo SY, et al. The effects of mesenchymal stem cells transduced with Akt in a porcine myocardial infarction model. Cardiovasc Res. 2006 Jun 1; 70(3):530-42. [PubMed: 16563361]

73. Mangi AA, Noiseux N, Kong D, He H, Rezvani M, Ingwall JS, et al. Mesenchymal stem cells modified with Akt prevent remodeling and restore performance of infarcted hearts. Nat Med. 2003 Sep; 9(9):1195-201. [PubMed: 12910262]

74. Gnecchi M, He H, Liang OD, Melo LG, Morello F, Mu H, et al. Paracrine action accounts for marked protection of ischemic heart by Akt-modified mesenchymal stem cells. Nat Med. 2005 Apr; 11(4):367-8. [PubMed: 15812508]

75. Liu XH, Bai CG, Xu ZY, Huang SD, Yuan Y, Gong DJ, et al. Therapeutic potential of angiogenin modified mesenchymal stem cells: angiogenin improves mesenchymal stem cells survival under 
hypoxia and enhances vasculogenesis in myocardial infarction. Microvasc Res. 2008 May; 76(1): 23-30. [PubMed: 18462761]

76. Wang X, Zhao T, Huang W, Wang T, Qian J, Xu M, et al. Hsp20-engineered mesenchymal stem cells are resistant to oxidative stress via enhanced activation of Akt and increased secretion of growth factors. Stem Cells. 2009 Dec; 27(12):3021-31. [PubMed: 19816949]

77. Li W, Ma N, Ong LL, Nesselmann C, Klopsch C, Ladilov Y, et al. Bcl-2 engineered MSCs inhibited apoptosis and improved heart function. Stem Cells. 2007 Aug; 25(8):2118-27. [PubMed: 17478584]

78. Tang YL, Tang Y, Zhang YC, Qian K, Shen L, Phillips MI. Improved graft mesenchymal stem cell survival in ischemic heart with a hypoxia-regulated heme oxygenase-1 vector. J Am Coll Cardiol. 2005 Oct 4; 46(7):1339-50. [PubMed: 16198853]

79. Ahmed RP, Haider KH, Shujia J, Afzal MR, Ashraf M. Sonic Hedgehog gene delivery to the rodent heart promotes angiogenesis via iNOS/netrin-1/PKC pathway. PLoS One. 2010; 5(1):e8576. [PubMed: 20052412]

80. Jiang S, Haider H, Idris NM, Salim A, Ashraf M. Supportive interaction between cell survival signaling and angiocompetent factors enhances donor cell survival and promotes angiomyogenesis for cardiac repair. Circ Res. 2006 Sep 29; 99(7):776-84. [PubMed: 16960098]

81. Yau TM, Kim C, Li G, Zhang Y, Weisel RD, Li RK. Maximizing ventricular function with multimodal cell-based gene therapy. Circulation. 2005 Aug 30; 112(9 Suppl):I123-8. [PubMed: 16159803]

82. Yau TM, Kim C, Li G, Zhang Y, Fazel S, Spiegelstein D, et al. Enhanced angiogenesis with multimodal cell-based gene therapy. Ann Thorac Surg. 2007 Mar; 83(3):1110-9. [PubMed: 17307468]

83. Das H, George JC, Joseph M, Das M, Abdulhameed N, Blitz A, et al. Stem cell therapy with overexpressed VEGF and PDGF genes improves cardiac function in a rat infarct model. PLoS One. 2009; 4(10):e7325. [PubMed: 19809493]

84. Chen HK, Hung HF, Shyu KG, Wang BW, Sheu JR, Liang YJ, et al. Combined cord blood stem cells and gene therapy enhances angiogenesis and improves cardiac performance in mouse after acute myocardial infarction. Eur J Clin Invest. 2005 Nov; 35(11):677-86. [PubMed: 16269017]

85. Abrescia P, Golino P. Free radicals and antioxidants in cardiovascular diseases. Expert Rev Cardiovasc Ther. 2005 Jan; 3(1):159-71. [PubMed: 15723584]

86. Cantor EJ, Mancini EV, Seth R, Yao XH, Netticadan T. Oxidative stress and heart disease: cardiac dysfunction, nutrition, and gene therapy. Curr Hypertens Rep. 2003 Jun; 5(3):215-20. [PubMed: 12724053]

87. Dhalla NS, Temsah RM, Netticadan T. Role of oxidative stress in cardiovascular diseases. J Hypertens. 2000 Jun; 18(6):655-73. [PubMed: 10872549]

88. Higashi Y, Nishioka K, Umemura T, Chayama K, Yoshizumi M. Oxidative stress, endothelial function and angiogenesis induced by cell therapy and gene therapy. Curr Pharm Biotechnol. 2006 Apr; 7(2):109-16. [PubMed: 16724945]

89. Levonen AL, Vahakangas E, Koponen JK, Yla-Herttuala S. Antioxidant gene therapy for cardiovascular disease: current status and future perspectives. Circulation. 2008 Apr 22; 117(16): 2142-50. [PubMed: 18427144]

90. Zima AV, Blatter LA. Redox regulation of cardiac calcium channels and transporters. Cardiovasc Res. 2006 Jul 15; 71(2):310-21. [PubMed: 16581043]

91. Wu J, Hecker JG, Chiamvimonvat N. Antioxidant enzyme gene transfer for ischemic diseases. Adv Drug Deliv Rev. 2009 Apr 28; 61(4):351-63. [PubMed: 19233238]

92. Li Q, Bolli R, Qiu Y, Tang XL, Murphree SS, French BA. Gene therapy with extracellular superoxide dismutase attenuates myocardial stunning in conscious rabbits. Circulation. 1998 Oct 6; 98(14):1438-48. [PubMed: 9760299]

93. Li Q, Bolli R, Qiu Y, Tang XL, Guo Y, French BA. Gene therapy with extracellular superoxide dismutase protects conscious rabbits against myocardial infarction. Circulation. 2001 Apr 10; 103(14):1893-8. [PubMed: 11294809]

94. Agrawal RS, Muangman S, Layne MD, Melo L, Perrella MA, Lee RT, et al. Pre-emptive gene therapy using recombinant adeno-associated virus delivery of extracellular superoxide dismutase 
protects heart against ischemic reperfusion injury, improves ventricular function and prolongs survival. Gene Ther. 2004 Jun; 11(12):962-9. [PubMed: 15029230]

95. Yang J, Marden JJ, Fan C, Sanlioglu S, Weiss RM, Ritchie TC, et al. Genetic redox preconditioning differentially modulates AP-1 and NF kappa B responses following cardiac ischemia/reperfusion injury and protects against necrosis and apoptosis. Mol Ther. 2003 Mar; 7(3): 341-53. [PubMed: 12668130]

96. Abunasra HJ, Smolenski RT, Morrison K, Yap J, Sheppard MN, O’Brien T, et al. Efficacy of adenoviral gene transfer with manganese superoxide dismutase and endothelial nitric oxide synthase in reducing ischemia and reperfusion injury. Eur J Cardiothorac Surg. 2001 Jul; 20(1): 153-8. [PubMed: 11423289]

97. Liu X, Simpson JA, Brunt KR, Ward CA, Hall SR, Kinobe RT, et al. Preemptive heme oxygenase-1 gene delivery reveals reduced mortality and preservation of left ventricular function 1 yr after acute myocardial infarction. Am J Physiol Heart Circ Physiol. 2007 Jul; 293(1):H48-59. [PubMed: 17322421]

98. Melo LG, Agrawal R, Zhang L, Rezvani M, Mangi AA, Ehsan A, et al. Gene therapy strategy for long-term myocardial protection using adeno-associated virus-mediated delivery of heme oxygenase gene. Circulation. 2002 Feb 5; 105(5):602-7. [PubMed: 11827926]

99. Liu X, Pachori AS, Ward CA, Davis JP, Gnecchi M, Kong D, et al. Heme oxygenase-1 (HO-1) inhibits postmyocardial infarct remodeling and restores ventricular function. FASEB J. 2006 Feb; 20(2):207-16. [PubMed: 16449792]

100. Dulak J, Jozkowicz A, Foresti R, Kasza A, Frick M, Huk I, et al. Heme oxygenase activity modulates vascular endothelial growth factor synthesis in vascular smooth muscle cells. Antioxid Redox Signal. 2002 Apr; 4(2):229-40. [PubMed: 12006174]

101. Tang YL, Qian K, Zhang YC, Shen L, Phillips MI. A vigilant, hypoxia-regulated heme oxygenase-1 gene vector in the heart limits cardiac injury after ischemia-reperfusion in vivo. J Cardiovasc Pharmacol Ther. 2005 Dec; 10(4):251-63. [PubMed: 16382261]

102. Tao L, Gao E, Bryan NS, Qu Y, Liu HR, Hu A, et al. Cardioprotective effects of thioredoxin in myocardial ischemia and reperfusion: role of S-nitrosation [corrected]. Proc Natl Acad Sci U S A. 2004 Aug 3; 101(31):11471-6. [PubMed: 15277664]

103. Tao L, Gao E, Hu A, Coletti C, Wang Y, Christopher TA, et al. Thioredoxin reduces postischemic myocardial apoptosis by reducing oxidative/nitrative stress. Br J Pharmacol. 2006 Oct; 149(3):311-8. [PubMed: 16921396]

104. Samuel SM, Thirunavukkarasu M, Penumathsa SV, Koneru S, Zhan L, Maulik G, et al. Thioredoxin-1 gene therapy enhances angiogenic signaling and reduces ventricular remodeling in infarcted myocardium of diabetic rats. Circulation. 2010 Mar 16; 121(10):1244-55. [PubMed: 20194885]

105. Jones SP, Greer JJ, Kakkar AK, Ware PD, Turnage RH, Hicks M, et al. Endothelial nitric oxide synthase overexpression attenuates myocardial reperfusion injury. Am J Physiol Heart Circ Physiol. 2004 Jan; 286(1):H276-82. [PubMed: 12969888]

106. Chen LL, Yin H, Huang J. Inhibition of TGF-beta1 signaling by eNOS gene transfer improves ventricular remodeling after myocardial infarction through angiogenesis and reduction of apoptosis. Cardiovasc Pathol. 2007 Jul-Aug; 16(4):221-30. [PubMed: 17637430]

107. Chen LL, Zhu TB, Yin H, Huang J, Wang LS, Cao KJ, et al. Inhibition of MAPK signaling by eNOS gene transfer improves ventricular remodeling after myocardial infarction through reduction of inflammation. Mol Biol Rep. 2009 Nov 12.

108. Smith RS Jr, Agata J, Xia CF, Chao L, Chao J. Human endothelial nitric oxide synthase gene delivery protects against cardiac remodeling and reduces oxidative stress after myocardial infarction. Life Sci. 2005 Apr 8; 76(21):2457-71. [PubMed: 15763077]

109. Kupatt C, Hinkel R, Vachenauer R, Horstkotte J, Raake P, Sandner T, et al. VEGF165 transfection decreases postischemic NF-kappa B-dependent myocardial reperfusion injury in vivo: role of eNOS phosphorylation. FASEB J. 2003 Apr; 17(6):705-7. [PubMed: 12586740]

110. Li Q, Guo Y, Tan W, Stein AB, Dawn B, Wu WJ, et al. Gene therapy with iNOS provides longterm protection against myocardial infarction without adverse functional consequences. Am $\mathrm{J}$ Physiol Heart Circ Physiol. 2006 Feb; 290(2):H584-9. [PubMed: 16172153] 
111. Li Q, Guo Y, Xuan YT, Lowenstein CJ, Stevenson SC, Prabhu SD, et al. Gene therapy with inducible nitric oxide synthase protects against myocardial infarction via a cyclooxygenase-2dependent mechanism. Circ Res. 2003 Apr 18; 92(7):741-8. [PubMed: 12702642]

112. Li Q, Guo Y, Ou Q, Cui C, Wu WJ, Tan W, et al. Gene transfer of inducible nitric oxide synthase affords cardioprotection by upregulating heme oxygenase-1 via a nuclear factor-\{kappa\}Bdependent pathway. Circulation. 2009 Sep 29; 120(13):1222-30. [PubMed: 19752329]

113. Okubo S, Wildner O, Shah MR, Chelliah JC, Hess ML, Kukreja RC. Gene transfer of heat-shock protein 70 reduces infarct size in vivo after ischemia/reperfusion in the rabbit heart. Circulation. 2001 Feb 13; 103(6):877-81. [PubMed: 11171798]

114. Zhu YH, Ma TM, Wang X. Gene transfer of heat-shock protein 20 protects against ischemia/ reperfusion injury in rat hearts. Acta Pharmacol Sin. 2005 Oct; 26(10):1193-200. [PubMed: 16174435]

115. Suzuki K, Murtuza B, Sammut IA, Latif N, Jayakumar J, Smolenski RT, et al. Heat shock protein 72 enhances manganese superoxide dismutase activity during myocardial ischemia-reperfusion injury, associated with mitochondrial protection and apoptosis reduction. Circulation. 2002 Sep 24; 106(12 Suppl 1):I270-6. [PubMed: 12354745]

116. Tenhunen O, Soini Y, Ilves M, Rysa J, Tuukkanen J, Serpi R, et al. p38 Kinase rescues failing myocardium after myocardial infarction: evidence for angiogenic and anti-apoptotic mechanisms. FASEB J. 2006 Sep; 20(11):1907-9. [PubMed: 16849392]

117. Mazure NM, Brahimi-Horn MC, Pouyssegur J. Protein kinases and the hypoxia-inducible factor-1, two switches in angiogenesis. Curr Pharm Des. 2003; 9(7):531-41. [PubMed: 12570801]

118. Lai ZF, Chen YZ, Feng LP, Meng XM, Ding JF, Wang LY, et al. Overexpression of TNNI3K, a cardiac-specific MAP kinase, promotes P19CL6-derived cardiac myogenesis and prevents myocardial infarction-induced injury. Am J Physiol Heart Circ Physiol. 2008 Aug; 295(2):H70816. [PubMed: 18552163]

119. Haider H, Jiang S, Idris NM, Ashraf M. IGF-1-overexpressing mesenchymal stem cells accelerate bone marrow stem cell mobilization via paracrine activation of SDF-1alpha/CXCR4 signaling to promote myocardial repair. Circ Res. 2008 Nov 21; 103(11):1300-8. [PubMed: 18948617]

120. Sugano M, Tsuchida K, Hata T, Makino N. In vivo transfer of soluble TNF-alpha receptor 1 gene improves cardiac function and reduces infarct size after myocardial infarction in rats. FASEB J. 2004 May; 18(7):911-3. [PubMed: 15117889]

121. Wang F, Trial J, Diwan A, Gao F, Birdsall H, Entman M, et al. Regulation of cardiac fibroblast cellular function by leukemia inhibitory factor. J Mol Cell Cardiol. 2002 Oct; 34(10):1309-16. [PubMed: 12392991]

122. Gadient RA, Patterson PH. Leukemia inhibitory factor, Interleukin 6, and other cytokines using the GP130 transducing receptor: roles in inflammation and injury. Stem Cells. 1999; 17(3):12737. [PubMed: 10342555]

123. Wang F, Seta Y, Baumgarten G, Engel DJ, Sivasubramanian N, Mann DL. Functional significance of hemodynamic overload-induced expression of leukemia-inhibitory factor in the adult mammalian heart. Circulation. 2001 Mar 6; 103(9):1296-302. [PubMed: 11238276]

124. Kodama H, Fukuda K, Pan J, Makino S, Baba A, Hori S, et al. Leukemia inhibitory factor, a potent cardiac hypertrophic cytokine, activates the JAK/STAT pathway in rat cardiomyocytes. Circ Res. 1997 Nov; 81(5):656-63. [PubMed: 9351438]

125. Berry MF, Pirolli TJ, Jayasankar V, Morine KJ, Moise MA, Fisher O, et al. Targeted overexpression of leukemia inhibitory factor to preserve myocardium in a rat model of postinfarction heart failure. J Thorac Cardiovasc Surg. 2004 Dec; 128(6):866-75. [PubMed: 15573071]

126. Kusano KF, Pola R, Murayama T, Curry C, Kawamoto A, Iwakura A, et al. Sonic hedgehog myocardial gene therapy: tissue repair through transient reconstitution of embryonic signaling. Nat Med. 2005 Nov; 11(11):1197-204. [PubMed: 16244652]

127. Agata J, Chao L, Chao J. Kallikrein gene delivery improves cardiac reserve and attenuates remodeling after myocardial infarction. Hypertension. 2002 Nov; 40(5):653-9. [PubMed: 12411458] 
128. Zuo H, Liu Z, Liu X, Yang J, Liu T, Wen S, et al. CD151 gene delivery after myocardial infarction promotes functional neovascularization and activates FAK signaling. Mol Med. 2009 Sep-Oct; 15(9-10):307-15. [PubMed: 19603100]

129. Wang L, Yang J, Liu ZX, Chen B, Liu J, Lan RF, et al. Gene transfer of CD151 enhanced myocardial angiogenesis and improved cardiac function in rats with experimental myocardial infarction. Zhonghua Xin Xue Guan Bing Za Zhi. 2006 Feb; 34(2):159-63. [PubMed: 16626587]

130. Miao W, Luo Z, Kitsis RN, Walsh K. Intracoronary, adenovirus-mediated Akt gene transfer in heart limits infarct size following ischemia-reperfusion injury in vivo. J Mol Cell Cardiol. 2000 Dec; 32(12):2397-402. [PubMed: 11113015]

131. Cittadini A, Monti MG, Iaccarino G, Di Rella F, Tsichlis PN, Di Gianni A, et al. Adenoviral gene transfer of Akt enhances myocardial contractility and intracellular calcium handling. Gene Ther. 2006 Jan; 13(1):8-19. [PubMed: 16094411]

132. Chinnaiyan AM, Orth K, O'Rourke K, Duan H, Poirier GG, Dixit VM. Molecular ordering of the cell death pathway. Bcl-2 and Bcl-xL function upstream of the CED-3-like apoptotic proteases. J Biol Chem. 1996 Mar 1; 271(9):4573-6. [PubMed: 8617712]

133. Brocheriou V, Hagege AA, Oubenaissa A, Lambert M, Mallet VO, Duriez M, et al. Cardiac functional improvement by a human $\mathrm{Bcl}-2$ transgene in a mouse model of ischemia/reperfusion injury. J Gene Med. 2000 Sep-Oct; 2(5):326-33. [PubMed: 11045426]

134. Chatterjee S, Stewart AS, Bish LT, Jayasankar V, Kim EM, Pirolli T, et al. Viral gene transfer of the antiapoptotic factor $\mathrm{Bcl}-2$ protects against chronic postischemic heart failure. Circulation. 2002 Sep 24; 106(12 Suppl 1):I212-7. [PubMed: 12354736]

135. Chatterjee S, Bish LT, Jayasankar V, Stewart AS, Woo YJ, Crow MT, et al. Blocking the development of postischemic cardiomyopathy with viral gene transfer of the apoptosis repressor with caspase recruitment domain. J Thorac Cardiovasc Surg. 2003 Jun; 125(6):1461-9. [PubMed: 12830068]

136. Kuwahara K, Saito Y, Kishimoto I, Miyamoto Y, Harada M, Ogawa E, et al. Cardiotrophin-1 phosphorylates akt and BAD, and prolongs cell survival via a PI3K-dependent pathway in cardiac myocytes. J Mol Cell Cardiol. 2000 Aug; 32(8):1385-94. [PubMed: 10900165]

137. Liao Z, Brar BK, Cai Q, Stephanou A, O'Leary RM, Pennica D, et al. Cardiotrophin-1 (CT-1) can protect the adult heart from injury when added both prior to ischaemia and at reperfusion. Cardiovasc Res. 2002 Mar; 53(4):902-10. [PubMed: 11922900]

138. Ruixing Y, Jinzhen W, Dezhai Y, Jiaquan L. Cardioprotective role of cardiotrophin-1 gene transfer in a murine model of myocardial infarction. Growth Factors. 2007 Aug; 25(4):286-94. [PubMed: 18092236]

139. Takuwa Y, Okamoto Y, Yoshioka K, Takuwa N. Sphingosine-1-phosphate signaling and biological activities in the cardiovascular system. Biochim Biophys Acta. 2008 Sep; 1781(9): 483-8. [PubMed: 18472021]

140. Duan HF, Wang H, Yi J, Liu HJ, Zhang QW, Li LB, et al. Adenoviral gene transfer of sphingosine kinase 1 protects heart against ischemia/reperfusion-induced injury and attenuates its postischemic failure. Hum Gene Ther. 2007 Nov; 18(11):1119-28. [PubMed: 17939750]

141. FM, Hartikainen J, Syvanne M, Stjernvall J, Hedman A, Kivela A, et al. Safety and feasibility of catheter-based local intracoronary vascular endothelial growth factor gene transfer in the prevention of postangioplasty and in-stent restenosis and in the treatment of chronic myocardial ischemia: phase II results of the Kuopio Angiogenesis Trial (KAT). Circulation. 2003 Jun 3; 107(21):2677-83. [PubMed: 12742981]

142. Hedman M, Muona K, Hedman A, Kivela A, Syvanne M, Eranen J, et al. Eight-year safety follow-up of coronary artery disease patients after local intracoronary VEGF gene transfer. Gene Ther. 2009 May; 16(5):629-34. [PubMed: 19212427]

143. Kastrup J, Jorgensen E, Ruck A, Tagil K, Glogar D, Ruzyllo W, et al. Direct intramyocardial plasmid vascular endothelial growth factor-A165 gene therapy in patients with stable severe angina pectoris A randomized double-blind placebo-controlled study: the Euroinject One trial. J Am Coll Cardiol. 2005 Apr 5; 45(7):982-8. [PubMed: 15808751]

144. Gyongyosi M, Khorsand A, Zamini S, Sperker W, Strehblow C, Kastrup J, et al. NOGA-guided analysis of regional myocardial perfusion abnormalities treated with intramyocardial injections of 
plasmid encoding vascular endothelial growth factor A-165 in patients with chronic myocardial ischemia: subanalysis of the EUROINJECT-ONE multicenter double-blind randomized study. Circulation. 2005 Aug 30; 112(9 Suppl):I157-65. [PubMed: 16159809]

145. Ripa RS, Wang Y, Jorgensen E, Johnsen HE, Hesse B, Kastrup J. Intramyocardial injection of vascular endothelial growth factor-A165 plasmid followed by granulocyte-colony stimulating factor to induce angiogenesis in patients with severe chronic ischaemic heart disease. Eur Heart J. 2006 Aug; 27(15):1785-92. [PubMed: 16825290]

146. Stewart DJ, Kutryk MJ, Fitchett D, Freeman M, Camack N, Su Y, et al. VEGF gene therapy fails to improve perfusion of ischemic myocardium in patients with advanced coronary disease: results of the NORTHERN trial. Mol Ther. 2009 Jun; 17(6):1109-15. [PubMed: 19352324]

147. Stewart DJ, Hilton JD, Arnold JM, Gregoire J, Rivard A, Archer SL, et al. Angiogenic gene therapy in patients with nonrevascularizable ischemic heart disease: a phase 2 randomized, controlled trial of AdVEGF(121) (AdVEGF121) versus maximum medical treatment. Gene Ther. 2006 Nov; 13(21):1503-11. [PubMed: 16791287]

148. Losordo DW, Vale PR, Hendel RC, Milliken CE, Fortuin FD, Cummings N, et al. Phase 1/2 placebo-controlled, double-blind, dose-escalating trial of myocardial vascular endothelial growth factor 2 gene transfer by catheter delivery in patients with chronic myocardial ischemia. Circulation. 2002 Apr 30; 105(17):2012-8. [PubMed: 11980678]

149. Reilly JP, Grise MA, Fortuin FD, Vale PR, Schaer GL, Lopez J, et al. Long-term (2-year) clinical events following transthoracic intramyocardial gene transfer of VEGF-2 in no-option patients. J Interv Cardiol. 2005 Feb; 18(1):27-31. [PubMed: 15788051]

150. Grines CL, Watkins MW, Helmer G, Penny W, Brinker J, Marmur JD, et al. Angiogenic Gene Therapy (AGENT) trial in patients with stable angina pectoris. Circulation. 2002 Mar 19; 105(11):1291-7. [PubMed: 11901038]

151. Grines CL, Watkins MW, Mahmarian JJ, Iskandrian AE, Rade JJ, Marrott P, et al. A randomized, double-blind, placebo-controlled trial of Ad5FGF-4 gene therapy and its effect on myocardial perfusion in patients with stable angina. J Am Coll Cardiol. 2003 Oct 15; 42(8):1339-47. [PubMed: 14563572]

152. Henry TD, Grines CL, Watkins MW, Dib N, Barbeau G, Moreadith R, et al. Effects of Ad5FGF-4 in patients with angina: an analysis of pooled data from the AGENT-3 and AGENT-4 trials. J Am Coll Cardiol. 2007 Sep 11; 50(11):1038-46. [PubMed: 17825712]

153. Su H, Joho S, Huang Y, Barcena A, Arakawa-Hoyt J, Grossman W, et al. Adeno-associated viral vector delivers cardiac-specific and hypoxia-inducible VEGF expression in ischemic mouse hearts. Proc Natl Acad Sci U S A. 2004 Nov 16; 101(46):16280-5. [PubMed: 15534198]

154. Tang Y. Gene therapy for myocardial ischemia using the hypoxia-inducible double plasmid system. Methods Mol Med. 2005; 112:37-47. [PubMed: 16010009]

155. Raty JK, Lesch HP, Wirth T, Yla-Herttuala S. Improving safety of gene therapy. Curr Drug Saf. 2008 Jan; 3(1):46-53. [PubMed: 18690980]

156. Phillips MI, Tang Y, Schmidt-Ott K, Qian K, Kagiyama S. Vigilant vector: heart-specific promoter in an adeno-associated virus vector for cardioprotection. Hypertension. $2002 \mathrm{Feb}$; 39(2 Pt 2):651-5. [PubMed: 11882625]

157. Fujii H, Sun Z, Li SH, Wu J, Fazel S, Weisel RD, et al. Ultrasound-targeted gene delivery induces angiogenesis after a myocardial infarction in mice. JACC Cardiovasc Imaging. 2009 Jul; 2(7): 869-79. [PubMed: 19608138]

158. Suzuki R, Takizawa T, Negishi Y, Utoguchi N, Maruyama K. Effective gene delivery with novel liposomal bubbles and ultrasonic destruction technology. Int J Pharm. 2008 Apr 16; 354(1-2): 49-55. [PubMed: 18082343]

159. Yockman JW, Kastenmeier A, Erickson HM, Brumbach JG, Whitten MG, Albanil A, et al. Novel polymer carriers and gene constructs for treatment of myocardial ischemia and infarction. $\mathrm{J}$ Control Release. 2008 Dec 18; 132(3):260-6. [PubMed: 18662730]

160. Yi F, Wu H, Jia GL, Guo WY, Lu AL, Wang HC, et al. Effect of nanoparticle with vascular endothelial growth factor gene transferred into ischemic myocardium: experiment with rabbits. Zhonghua Yi Xue Za Zhi. 2006 Feb 28; 86(8):510-4. [PubMed: 16681877] 


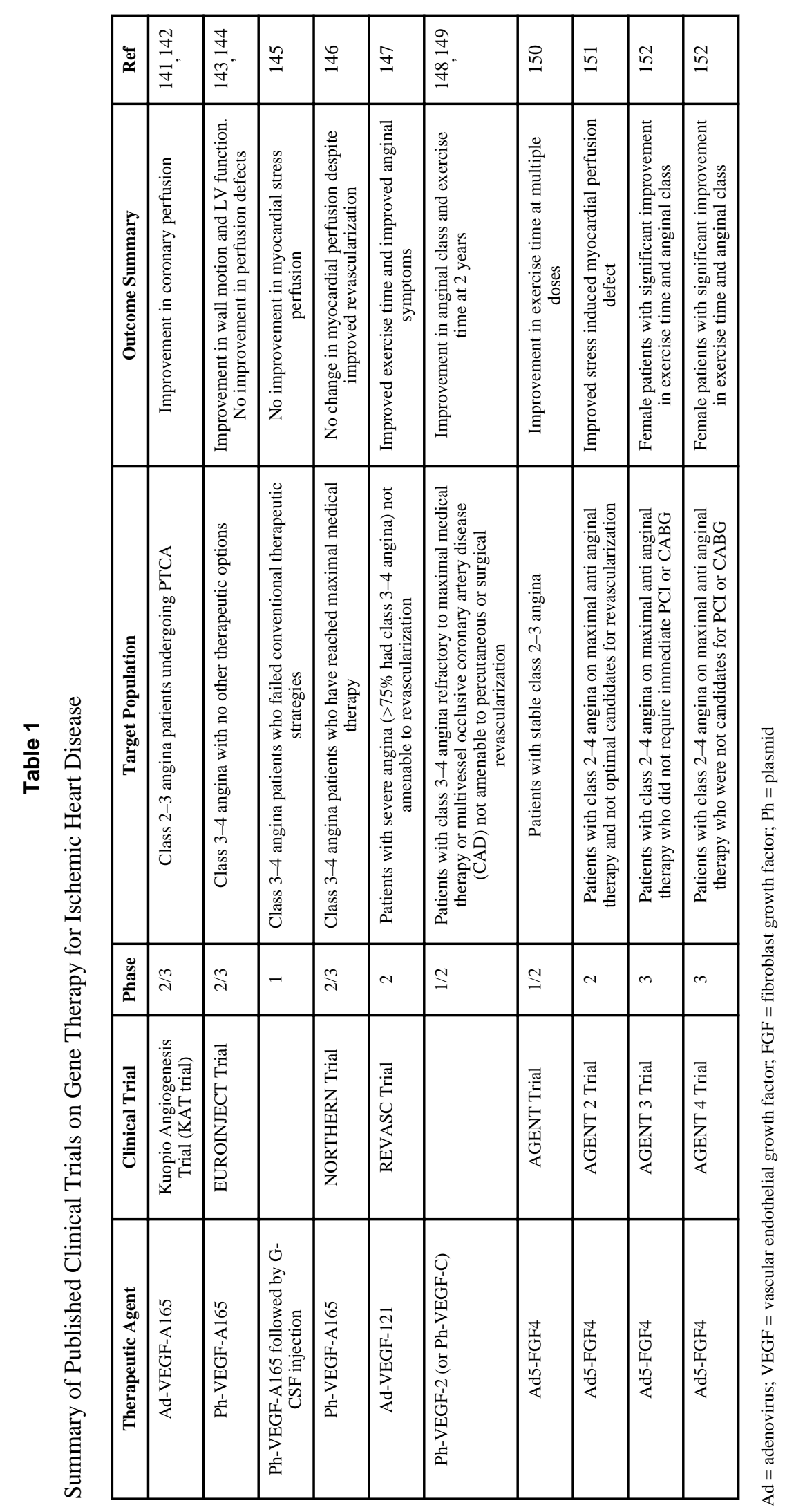

J Mol Cell Cardiol. Author manuscript; available in PMC 2012 May 1. 